\title{
Azolla microphylla and Pseudomonas aeruginosa for bioremediation of bioethanol wastewater
}

\author{
KHOIRUL ANNISA ${ }^{1, \boldsymbol{\nu}}$, SUTARNO ${ }^{2}$, SLAMET SANTOSA ${ }^{3}$ \\ ${ }^{1}$ Graduate Program in Environmental Science, Graduate School, Universitas Sebelas Maret. Jl. Ir. Sutami 36A, Surakarta 57126, Central Java, Indonesia. \\ Tel./fax. +62-271-663375, `email: khoirulannisa2112@gmail.com. \\ ${ }^{2}$ Department of Biology, Faculty of Mathematics and Natural Sciences, Universitas Sebelas Maret. Jl. Ir. Sutami 36A, Surakarta 57126, Central Java, \\ Indonesia \\ ${ }^{3}$ Department of Biology Education, Faculty of Teacher Training and Education, Universitas Sebelas Maret. J1. Ir. Sutami 36A, Surakarta 57126, Central \\ Java, Indonesia
}

Manuscript received: 15 June 2020. Revision accepted: 19 March 2021.

\begin{abstract}
Annisa K, Sutarno, Santosa S. 2021. Azolla microphylla and Pseudomonas aeruginosa for bioremediation of bioethanol wastewater. Biodiversitas 22: 1799-1805. Bioremediation is the right choice in wastewater treatment since it requires has low cost but works optimally. Azolla microphylla and Pseudomonas aeruginosa are considered to have the ability to optimize waste degradation. The aim of this study was to determine the best treatment for reducing pollutants in bioethanol waste, namely by using A. microphylla and $P$. aeruginosa. The twelve treatments in this experimental research included variations in the A. microphylla biomass and variations of biomass combinations with the density of the P. aeruginosa. Research method used was completely randomized design with three replications, and all 36 samples were taken on the seventh day. Research data collected were the quality parameters of bioethanol wastewater before and after the treatment. The results showed that TSS, BOD, COD were decreased during seven days of treatment, whereas $\mathrm{pH}$ and $\mathrm{H}_{2} \mathrm{~S}$ levels were increased. The combination of $0.2 \mathrm{~kg}$ A. microphylla and $10^{10} \mathrm{cfu} / \mathrm{mL} P$. aeruginosa showed the best result in reducing pollutants. This study showed that $A$. microphylla and $P$. aeruginosa could be used to reduce pollutants in bioethanol wastewater. Results of the research are expected to become an alternative solution to the bioethanol wastewater problem.
\end{abstract}

Keywords: Azolla microphylla, Pseudomonas aeruginosa, bioremediation, wastewater

\section{INTRODUCTION}

Waste discharged directly into the environment without treatment will contaminate the environment. In addition, the disposal of waste directly into the environment may get protests from the surrounding community as happened with the waste of the bioethanol industry. Therefore, waste should be treated first before being discharged into the environment. However, the cost for waste treatment is very high, so it is necessary to develop wastewater treatment methods that can process waste optimally at a low budget. A cheap alternative for degrading wastewater pollutants is bioremediation, namely the use of biological interventions to mitigate the effects of toxins caused by pollutants (Soman et al. 2018). Biological interventions can be carried out using microorganisms, plants, or other living things. One of the bioremediation methods utilizes, Azolla microphylla, an aquatic fern in the family Salviaceae which has roots without fibers (Sood et al. 2011), a soft leaf surface, which can fix $\mathrm{N}_{2}$ in the air and live in symbiosis with Anabaena azollae or bacteria (Carrapiço 2017). A. microphylla rapidly multiplies to form biomass and can be found in the rice fields, so it is easy to obtain this plant.

Previous research conducted by Unisah and Akbari (2020) showed that the use of A. microphylla in tofu wastewater treatment reduced $96 \%$ of BOD, $96 \%$ COD, $97 \%$ TSS, and neutralize pH. A. microphylla is also able to prevent eutrophication, reducing organic pollutants by
$33.3 \%$ and organic carbon by $50 \%$ in wastewater (Soman et al. 2018). Nurcahyani (2015) states that the bioethanol wastewater industry contains high organic glucose, which is $1.3285 \%$. Therefore, A. microphylla is suitable for use in the treatment of bioethanol industrial wastewater. $A$. microphylla growth can be induced by the rhizobacteria such as Pseudomonas sp. which acts as a biofertilizer and biostimulant. Pseudomonas aeruginosa produces auxin which plays a role in cell division, cell elongation, lateral root formation and provides phosphate for A. microphylla nutrition (Mardhiana et al. 2017; Santosa et al. 2018; Astriani et al. 2020). Phosphate is a macro element needed for the growth of A. microphylla (Utama et al. 2015). Pseudomonas sp. also considered potential as a biocontrol agent in plant diseases, further referred to as endophytic bacteria or endophytic bacteria (Mardhiana et al. 2017; Warzatullisna et al. 2019; Wiratno et al. 2019). The combination of A. microphylla and bacteria is considered to optimize the process of waste degradation. Interaction between plants and bacteria in areas contaminated with waste can increase the growth of these plants and the effectiveness of the phytoremediation process (Khan et al. 2015; Furini et al. 2015). Ekyastuti's research (2018) showed that Pseudomonas sp. increased the growth of Jatropha curcas thereby optimizing waste remediation. A. microphylla can live in symbiosis with bacteria to support its growth (Carrapiço 2017). 
Previous study conducted by Romayanto et al. (2006) showed that Pseudomonas bacteria in domestic waste treatment decreased oil, fat, BOD and TSS levels and increased $\mathrm{pH}$. $P$. aeruginosa belongs to a strain of bacteria that can degrade organic waste (Austin 1988). $P$. aeruginosa is a Gram-negative, rod-shaped bacterium found in agricultural water, sewage and hospital wastes (Chellaiah 2018). Pseudomonas sp. is an important factor in the carbon cycle, so these bacteria are often used as waste bioremediation agents. Microorganisms use wastewater as their growth nutrition (Shah et al. 2013). Pseudomonas sp. decomposes protein (Wahyudi et al. 2019), cellulose, hemicellulose, starch, chitin, pectin, inulin, lignin (Rao 1994) into simpler compounds and produces enzymes protease, lipase, catalase, chitinase and amylase (Mardhiana et al. 2017). Lipase enzymes decompose oils and fats contained in waste.

This study aimed to determine the best treatment for reducing pollutants in bioethanol waste, using $A$. microphylla and P. aeruginosa.

\section{MATERIALS AND METHODS}

\section{Study area}

The location of this research was the bioethanol home industry center of Sukoharjo District, Central Java, Indonesia, namely Karangwuni Village, Ngombakan Village, and Bekonang Village. This industry has been run since the $1940 \mathrm{~s}$ and is widely known in Indonesia. Meanwhile, for the process of bacterial dilution, the manufacture of bacteria growing media and the making of bacterial stocks was carried out at the Biology Education Microbiology Laboratory of Sebelas Maret University (UNS), Surakarta, Indonesia. The research was carried out from January to April 2020.

\section{Procedures}

Propagation of the bacterium Pseudomonas aeruginosa inoculum

The bacterium used in the treatment was $P$. aeruginosa. According to Shah et al. (2013) Pseudomonas sp. is a bacterium often used as a bioremediation agent. $P$. aeruginosa bacterial inoculum was obtained from the Laboratory of the Department of Agricultural Microbiology, Gadjah Mada University (UGM), Yogyakarta, Indonesia. Bacteria from Nutrient Agar (NA) slope were grown on $900 \mathrm{~mL}$ of Nutrient Broth (NB) for 24 hours and re-incubated for 24 hours at $37^{\circ} \mathrm{C}$. Transfer of $10 \%$ of the inoculum into a new medium was done every day, aimed to maintain the supply of inoculum during the study. The concentrations of inoculums used were $10^{8}$ $\mathrm{cfu} / \mathrm{mL}, 10^{9} \mathrm{cfu} / \mathrm{mL}, 10^{10} \mathrm{cfu} / \mathrm{mL}$. The inoculum was then mixed with the bioethanol wastewater to be used in the experiment.

\section{Azolla microphylla acclimatization}

Azolla microphylla was taken from a farmhouse in the Polokarto Subdistrict, Sukoharjo District, Central Java, Indonesia and then put into an acclimation pond. $A$. microphylla was subsequently acclimatized for one week before being used in the experiment. During the acclimatization process, the growth of the plants was observed to determine their resistance to the new environment. Observation and testing of the sample water quality parameters were also carried out before treatment. After the propagation of the $P$. aeruginosa and the acclimatization of $A$. microphylla was completed, the next step was testing the pre-treatment parameters of the bioethanol wastewater samples, i.e., $\mathrm{pH}$, TSS, BOD, COD and sulfide material. These assays were conducted at the Center for Environmental Health and Disease Control Engineering, Yogyakarta.

\section{Bioethanol wastewater treatment process}

Each treatment tank was filled with $50 \mathrm{~mL}$ of wastewater and added with water until it reached a volume of 10 liters. The original waste was diluted to obtain a waste $\mathrm{pH}$ of 6.5 and the concentration of waste to $0.5 \%$ because Azolla sp. lives at pH $5.5-6.5$ and P. aeruginosa lives at $\mathrm{pH}$ 6.5-7.5 (Maslahat et al. 2010). Ewies et al. (1998) say that almost all bacteria like neutral conditions, since strong acidic or alkaline conditions can inhibit the activity of microorganisms. There were twelve treatments in this stage. The treatment consisted of a variety of $A$. microphylla biomass, which weighed: a) $0.1 \mathrm{~kg}$, b) $0.15 \mathrm{~kg}$, c) $0.2 \mathrm{~kg}$ and variations in the combination of $A$. microphylla biomass and the density of the $P$. aeruginosa bacteria, i.e., d) $0.1 \mathrm{~kg}$ and $10^{8} \mathrm{cfu} / \mathrm{mL}$, e) $0.15 \mathrm{~kg}$ and $10^{8}$ $\mathrm{cfu} / \mathrm{mL}, \mathrm{f}) 0.2 \mathrm{~kg}$ and $\left.10^{8} \mathrm{cfu} / \mathrm{mL}, \mathrm{g}\right) 0.1 \mathrm{~kg}$ and $10^{9}$ $\mathrm{cfu} / \mathrm{mL}, \mathrm{h}) 0.15 \mathrm{~kg}$ and $10^{9} \mathrm{cfu} / \mathrm{mL}$, i) $0.2 \mathrm{~kg}$ and $10^{9}$ $\mathrm{cfu} / \mathrm{mL}, \mathrm{j}) 0.1 \mathrm{~kg}$ and $\left.10^{10} \mathrm{cfu} / \mathrm{mL}, \mathrm{k}\right) 0.15 \mathrm{~kg}$ and $10^{10}$ $\mathrm{cfu} / \mathrm{mL}, 1) 0.2 \mathrm{~kg}$ and $10^{10} \mathrm{cfu} / \mathrm{mL}$. Each treatment was done in three replicates and incubated for seven days at $37^{\circ}$ C. Research by Mentari et. al (2016) showed that the most effective of Azolla sp. contact duration was 7 days. On the seventh day, a total of 36 samples of bioethanol wastewater were taken and assayed.

\section{Observation and sample water quality parameters testing after treatment}

After the treatment in the experiment, the morphology of A. microphylla was observed and documented. Bioethanol wastewater samples were taken to further test water quality parameters for $\mathrm{pH}$, TSS, BOD, COD, and sulfide material $\left(\mathrm{H}_{2} \mathrm{~S}\right)$. The $\mathrm{pH}$ test was carried out by researcher using a $\mathrm{pH}$ meter while testings the quality parameters of bioethanol wastewater, i.e., TSS, BOD, $\mathrm{COD}$, and sulfide material $\left(\mathrm{H}_{2} \mathrm{~S}\right)$ were conducted at the Center for Environmental Health and Disease Control Engineering, Yogyakarta. Parameter testing methods used were the In House Method for TSS test, SNI 6989.2-2009 for COD test, SNI 6989.72-2009 for BOD test, and SNI 6989.70-2009 for sulfide test $\left(\mathrm{H}_{2} \mathrm{~S}\right)$.

\section{Data analysis}

According to the Minister of Environment Regulation number 5 of 2014 concerning Wastewater Quality Standards, the data of wastewater quality were compared to bioethanol wastewater quality standards consisting of $\mathrm{pH}$, 
TSS, BOD, COD, and sulfide content $\left(\mathrm{H}_{2} \mathrm{~S}\right)$. Data analysis was carried out before (pre-test) and after (post-test) the treatment process. The effectiveness of the reduction in levels was calculated for each parameter of the quality of wastewater in each treatment sample. The formula for calculating the effectiveness of reducing the level of wastewater quality parameters (Rohmah et al. 2019) was as follows,

\section{The effectiveness of wastewater quality treatment = Pretest level-posttest level pretest level}

The data were tested with Anova and further analyzed with Borda method to find the best treatment.

\section{RESULTS AND DISCUSSION}

The characteristics of bioethanol wastewater taken from bioethanol home industry center of Sukoharjo District, Central Java, Indonesia and the characteristics of diluted wastes are described in Table 1. The levels of TSS, COD, $\mathrm{BOD}$ and $\mathrm{pH}$ exceeded the quality standard values, so treatment was required to reduce these pollutant levels.

\section{Total Suspended Solids (TSS) Reduction}

The highest decrease in TSS levels occurred in the I $\left(0.2 \mathrm{~kg}\right.$ and $\left.10^{9} \mathrm{cfu} / \mathrm{mL}\right)$, i.e., $31.9 \%$, while the lowest in the treatment $\mathrm{D}\left(0.1 \mathrm{~kg}\right.$ and $\left.10^{8} \mathrm{cfu} / \mathrm{mL}\right)$, i.e., $-90.48 \%$. ANOVA test showed there was a significant difference between the treatment groups. Azolla biomass and a combination of Azolla biomass and Pseudomonas bacterial density had a significant effect on the TSS. TSS is the amount of suspended substances in wastewater. The decrease of TSS level was caused by the ability of $A$. microphylla as a biofilter (Xin et al. 2008), which can absorb and accumulate nutrients in the roots (Ekyastuti et al. 2018; Parbo et al. 2019). In this case, A. microphylla could accumulate large amounts of contaminants into the biomass (Arora et al. 2006). The study by Sheena and
Harsha (2018) also revealed that the high reduction in solids was caused by the ability of plant roots to accumulate organic matter in wastewater that supports its growth. Aquatic plants absorb pollutants through direct root contact with contaminated water (Sood et al. 2011). $P$. aeruginosa expresses biosorption characteristics and promotes plant growth and pollutant accumulation by plants (Chellaiah 2018). P. aeruginosa can be used as suitable biosorbent for the removal of pollutants from solution, contaminated waste, water and soil. The decrease of TSS level was also caused by bacteria such as $P$. aeruginosa which can digest the organic substances contained in the waste. Previous study conducted by Romayanto et al. (2006) showed that the use of Pseudomonas bacteria in domestic waste treatment decreased TSS levels by $22.09 \%$. Waste has been decomposed by bacteria and produces compounds that can be used for bacterial growth (Romayanto et al. 2006). Pseudomonas sp. decomposes protein (Wahyudi et al. 2019), cellulose, hemicellulose, starch, chitin, pectin, inulin, lignin (Rao 1994) into simpler compounds with the help of the enzymes protease, lipase, catalase, chitinase and amylase (Mardhiana et al. 2017). Therefore, solids that are suspended in the waste are reduced.

\section{Chemical Oxygen Demand (COD) reduction}

The highest percentage of COD decrease occurred in the treatment $\mathrm{F}\left(0.2 \mathrm{~kg}\right.$ and $\left.10^{8} \mathrm{cfu} / \mathrm{mL}\right)$ which was 62.66 $\%$ and the lowest percentage was in the treatment $\mathrm{D}(0.1 \mathrm{~kg}$ and $\left.10^{8} \mathrm{cfu} / \mathrm{mL}\right)$, i.e., $54.45 \%$. Based on ANOVA test, there was no significant difference among the treatment groups. Azolla biomass and a combination of Azolla biomass and Pseudomonas bacterial density had no significant effect on the COD. The COD is the amount of oxygen needed to oxidize organic compounds in chemical waste, indicating the organic content in waste (Jenie and Rahayu 1996). The decrease in level of COD is caused by plants oxidizing the pollutant inside their tissues and bioconcentrate these substances (Varghese and Jacob 2016).

Table 1. Test results of bioethanol wastewater parameter on various treatments

\begin{tabular}{|c|c|c|c|c|c|c|c|c|}
\hline \multirow{2}{*}{$\begin{array}{l}\text { Treatment } \\
(\mathrm{kg}, \mathrm{cfu} / \mathrm{mL})\end{array}$} & \multicolumn{2}{|l|}{ TSS } & \multicolumn{2}{|l|}{ COD } & \multicolumn{2}{|l|}{ BOD } & \multirow{2}{*}{$\begin{array}{l}\mathrm{H}_{2} \mathrm{~S} \\
(\mathrm{mg} / \mathrm{L})\end{array}$} & \multirow{2}{*}{ pH } \\
\hline & $C^{*}(\mathrm{mg} / \mathrm{L})$ & $\mathbf{R}^{*}(\%)$ & $\mathrm{C}^{*}(\mathrm{mg} / \mathrm{L})$ & $\mathbf{R}^{*}(\%)$ & $\mathrm{C}^{*}(\mathrm{mg} / \mathrm{L})$ & $\mathbf{R}^{*}(\%)$ & & \\
\hline A0.1 & 70 & 7.14 & 596 & 56.16 & 134 & 79.24 & 0.17 & 8.1 \\
\hline A 0.15 & 72 & 7.62 & 565 & 58.49 & 115 & 82.23 & 0.14 & 8 \\
\hline A 0.2 & 81 & 26.67 & 564 & 58.55 & 138 & 78.70 & 0.15 & 7.7 \\
\hline A0.1 P10 8 & 133 & -90.48 & 620 & 54.45 & 172 & 73.36 & 0.27 & 7.7 \\
\hline A $0.15 \mathrm{P} 10^{8}$ & 56 & 19.52 & 532 & 60.88 & 147 & 77.23 & 0.09 & 7.8 \\
\hline $\mathrm{A} 0.2 \mathrm{P} 10^{8}$ & 64 & 9.05 & 508 & 62.66 & 129 & 80.01 & 0.14 & 7.9 \\
\hline A 0.1 P $10^{9}$ & 70 & 1.90 & 553 & 59.35 & 134 & 79.29 & 0.14 & 7.9 \\
\hline A0.15 P10 & 59 & 16.19 & 570 & 58.13 & 138 & 78.62 & 0.28 & 7.9 \\
\hline A 0.2 P $10^{9}$ & 48 & 31.90 & 536 & 60.59 & 181 & 82.38 & 0.12 & 8.1 \\
\hline A0.1 P10 10 & 59 & 17.14 & 542 & 60.15 & 182 & 71.87 & 0.11 & 7.9 \\
\hline A0.15 P10 10 & 59 & 16.67 & 557 & 59.04 & 181 & 71.92 & 0.45 & 7.8 \\
\hline A 0.2 P $10^{10}$ & 68 & 6.19 & 572 & 57.94 & 191 & 70.48 & 0.31 & 7.9 \\
\hline Original waste & 11.400 & & 263.500 & & 59.100 & & 4.13 & 4.4 \\
\hline Diluted waste & 70 & & 1360 & & 647 & & 0.0694 & 6.5 \\
\hline
\end{tabular}

Note: A: Biomass of Azolla microphylla, P: Density of Pseudomonas aeruginosa, C: The average of pollutant levels, R: Reduction of pollutant 
Research by Arora et al. (2006) revealed that $A$. microphylla had the highest bioconcentration potential among the genus Azolla species. The presence of these plants in wastewater can reduce $\mathrm{CO}_{2}$ used for photosynthesis and increase DO water leading to aerobic conditions in wastewater, which results in the reduction of BOD and COD (Sheena and Harsha 2018). Research conducted by Unisah and Akbari (2020) showed that the use of A. microphylla in tofu wastewater treatment reduced $96 \%$ of COD.

Pseudomonas aeruginosa oxidizes glucose (Jawetz 2010), mostly in bioethanol waste (Nurcahyani 2015), so bioethanol pollutants become decomposed. Organic matter in bioethanol wastewater can be a source of carbon nutrition for microbes (Tangahu et al. 2019). Other researchers also confirm that the reduction in COD can be caused by oxidation of organic matter in wetland systems that provide energy for microbial metabolism. In other words, the reduction of organic components is the result of biological decomposition by microorganisms. Reaction in oxidation of organic waste according to Romayanto (2006) are as follows,

$$
\left(\mathrm{CH}_{2} \mathrm{O}\right) \mathrm{n}+\mathrm{nO}_{2} \longrightarrow \mathrm{nCO}_{2}+\mathrm{nH}_{2} \mathrm{O}+\text { energy }
$$

$\mathrm{CO}_{2}$ and $\mathrm{H}_{2} \mathrm{O}$ from that reaction are potentially absorbed by the plants. $P$. aeruginosa plays a key role in phytoextraction process of plant (Chellaiah 2018), biofilm production (Wahyudi et al. 2019) and plant growthpromoting rhizobacteria activity (Santosa et al. 2018). Phytoremediation is influenced by the growth of plants and microorganisms associated with the rhizosphere (Sheena and Harsha 2018). Rhizosphere in plants stimulates microbial activity and community density by providing root surface area for their growth (Tanner 2001; Vymazal and Kropfelov 2009). Many fluorescent Pseudomonas strains, for example, $P$. aeruginosa which colonize the rhizosphere exert a protective effect on the roots through the production of in situ antibiotic compounds that promote growth and inhibit microbial infections (Jenni et al. 1989; Wackett 2000).

\section{Biochemical Oxygen Demand (BOD) Reduction}

The highest percentage of BOD decrease occurred in the treatment I $\left(0.2 \mathrm{~kg}\right.$ and $\left.10^{9} \mathrm{cfu} / \mathrm{mL}\right)$, i.e., $82.38 \%$ and the lowest percentage occurred in the treatment $\mathrm{L}(0.2 \mathrm{~kg}$ and $10^{10} \mathrm{cfu} / \mathrm{mL}$ ), i.e., $70.48 \%$. The Anova analysis showed significant differences among the treatment groups. Azolla biomass and a combination of Azolla biomass and Pseudomonas bacterial density significantly affected the BOD. The decrease in BOD is due to the decrease of oxygen demand by microorganisms for decomposing organic matter and the increase of dissolved oxygen (DO) in the water due to photosynthetic activity (Morrice et al. 2008) which produces oxygen. $P$. aeruginosa plays an important role in the breakdown of organic matter in bioethanol wastewater. Microorganisms decompose organic matter to obtain nutrients (Suhendrayatna et al.
2012). Reaction in cell oxidation according to Romayanto (2006) are as follows,

$$
\mathrm{Cell}+\mathrm{O}_{2} \longrightarrow \mathrm{CO}_{2}+\mathrm{H}_{2} \mathrm{O}+\mathrm{NH}_{3}+\text { energy }
$$

Pseudomonas sp. can decompose organic matter like proteins and carbohydrates into simpler compounds by secreted protease, lipase and amylase enzyme. Organic matter contained in wastewater provides substrate for microbial metabolism and the time of culture incubation can reduce the concentration of BOD in wastewater (Prabu 2007). This indicates that the reduction in BOD concentration in this study was influenced by $P$. aeruginosa which can break down the organic components. Romayanto et al. (2006) showed that the use of Pseudomonas bacteria in domestic waste treatment decreased BOD levels to 71,48 \%.

The BOD is the amount of $\mathrm{O}_{2}$ needed to decompose organic compounds in biological waste and indicates the decrease in BOD level in this study also occurred due to decomposition of organic matter by A. microphylla. Organic matter evaporates from the stems and leaves through a direct phytovolatilization mechanism or from the soil through root activity called indirect phytovolatilization mechanism (Limmer and Burken 2016; Ekta and Modi 2018). Phytoremediation agents such as A. microphylla absorb components from the environment which are then processed in the tissue metabolism to remove pollutants (Alkorta et al. 2004; Tulod et al. 2012; Varghese and Jacob 2016; Napaldet et al. 2019). Unisah and Akbari (2020) showed that the use of A. microphylla in tofu wastewater treatment reduced $96 \%$ of BOD.

\section{pH}

The highest percentage of $\mathrm{pH}$ increase occurred in the treatments A $(0.1 \mathrm{~kg})$, i.e., $24.1 \%$ and $\mathrm{I}\left(0.2 \mathrm{~kg}\right.$ and $10^{9}$ $\mathrm{cfu} / \mathrm{mL})$, i.e., $24.1 \%$ while the lowest percentage is in the treatments $\mathrm{C}(0.2 \mathrm{~kg})$ and $\mathrm{F}\left(0.1 \mathrm{~kg}\right.$ and $\left.10^{8} \mathrm{cfu} / \mathrm{mL}\right)$ which were $18.97 \%$ and $18.97 \%$ respectively. ANOVA test showed that there were significant differences among the treatment groups. Azolla biomass and a combination of Azolla biomass and Pseudomonas bacterial density significantly affected the $\mathrm{pH}$. The acidic condition of bioethanol wastewater was due to the addition of sodium metabisulfite $\left(\mathrm{Na}_{2} \mathrm{~S}_{2} \mathrm{O}_{5}\right)$ and $\mathrm{NaHSO}_{4}$ added in the production process of microbial nutrition. The $\mathrm{NaHSO}_{4}$ is a weak electrolyte salt that decreases pH (Sanna et al. 2017). It can be inferred that the incomplete decomposition of molecules causes the acidic condition in weak electrolyte salts. The $\mathrm{HSO}_{4}{ }^{-}$ion resulted from dissociation of $\mathrm{NaHSO}_{4}$ will reduce $\mathrm{pH}$ when it reacts to the water. This is what causes the bioethanol wastewater tends to be acidic (Kurniawati et al. 2015).

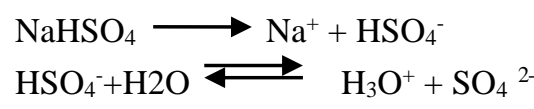


The increase of $\mathrm{pH}$ after treatment enabled $A$. microphylla to bind acids in wastewater. Increase in $\mathrm{pH}$ occurred due to photosynthesis by plants. Intake of $\mathrm{H}^{+}$ions in water for photosynthesis decreases the $\mathrm{H}^{+}$ion content, so the $\mathrm{pH}$ of the water increases (Ugya et al. 2019). The increase in $\mathrm{pH}$ is also caused by the breakdown of organic matter in water by microorganisms. The decomposition of organic matter by microorganisms will produce $\mathrm{OH}^{-}$in the form of $\mathrm{H}_{2} \mathrm{O}$, thereby supporting an increase in $\mathrm{pH}$. The activity of microorganisms decomposing organic material in waste is also related to photosynthesis activity, which takes dissolved $\mathrm{CO}_{2}$, resulting in an increase in $\mathrm{pH}$ (Morrice et al. 2008). Arnol et al. (2018) showed that the increase in $\mathrm{pH}$ is also related to reduce $\mathrm{SO}_{4}{ }^{2-}$ to $\mathrm{H}_{2} \mathrm{~S}$. The activity of bacteria in reducing sulfate to sulfide causes an increase in $\mathrm{pH}$ and sulfide level.

\section{Sulfides $\left(\mathrm{H}_{2} \mathrm{~S}\right)$ reduction}

The highest percentage of the decrease of $\mathrm{H}_{2} \mathrm{~S}$ level occurred in the treatment $\mathrm{E}\left(0.15 \mathrm{~kg}\right.$ and $\left.10^{8} \mathrm{cfu} / \mathrm{mL}\right)$ which is $-29 \%$ and the lowest percentage in the treatment $\mathrm{K}\left(0.15 \mathrm{~kg}\right.$ and $\left.10^{10} \mathrm{cfu} / \mathrm{mL}\right)$ which is $-544 \%$. ANOVA showed no significant difference among the treatment groups. Azolla biomass and a combination of Azolla biomass and Pseudomonas bacterial density had no significant effect on the $\mathrm{H}_{2} \mathrm{~S}$. The increase of sulfide $\left(\mathrm{H}_{2} \mathrm{~S}\right)$ in wastewater is caused by the use of wastewater by microorganisms as growth nutrients (Shah et al. 2013) which produces compounds such as $\mathrm{H}_{2} \mathrm{~S}$. Hydrogen sulfide $\left(\mathrm{H}_{2} \mathrm{~S}\right)$ is corrosive to metals, forming greenhouse gases $\left(\mathrm{SO}_{2}\right.$ or $\left.\mathrm{SO}_{3}\right)$ if it is burned and toxic at certain concentrations is toxic. $\mathrm{H}_{2} \mathrm{~S}$ can be found in wastes, quarries and crude oil (Qaisar et al. 2007). $\mathrm{H}_{2} \mathrm{~S}$ comes from the breakdown of compounds containing sulfur by bacteria. Sulfate-reducing bacteria utilize sulfur ions in the form of sulfate $\left(\mathrm{SO}_{4}{ }^{2-}\right)$, thiosulfate $\left(\mathrm{S}_{2} \mathrm{O}_{3}{ }^{2-}\right)$ and sulfite $\left(\mathrm{SO}_{3}{ }^{2-}\right)$ as terminal electron acceptors in their metabolic respiration, which is then reduced to sulfide. Reaction in releasing sulfides according to Arnol et al. (2018) are as follows,

$$
\mathrm{SO}_{4}{ }^{2-} \longrightarrow \mathrm{HS}^{-}
$$

The activity of bacteria reduces sulfate to sulfide causes an increase in the level of sulfide. Jorgensen (1982) reported that the number and activity of sulfate-reducing bacteria increased with the thickness of the sedimentary layer. Roots of aquatic plants such as A. microphylla can bind the nutrients and form the pollutant sedimentation (Arora et al. 2006), which increased the activity of sulfatereducing bacteria and the level of sulfide. $\mathrm{pH}$ and oxygen also affect the formation of sulfides, i.e., at $\mathrm{pH}<7$ forming $\mathrm{H}_{2} \mathrm{~S}$, at $\mathrm{pH}$ 7-9 $\mathrm{HS}^{-}$and at $\mathrm{pH}>8 \mathrm{~S}_{2}^{-}$(Markl 1999; Sanchez et al. 2005).

The results of Borda method showed that the best treatment in reducing pollutants in bioethanol wastewater was $0.2 \mathrm{~kg}$ of biomass with a bacterial density of $10^{10}$ $\mathrm{cfu} / \mathrm{mL}$. The treatment with the highest biomass and bacterial density will give the best results in reducing bioethanol wastewater levels. The greater the biomass, the more the organic matter is decomposed by plants. The treatment in the form of a combination of plants and bacteria in waste bioremediation showed better results. Plants and microorganisms are work synergistically for the treatment of waste in various media (Etim 2012). Research by Germaine et al. (2015) showed that plants and microorganisms form an association during reclamation of land polluted by organic contaminants. Interaction between plants and bacteria in contaminated areas can increase plant growth and the effectiveness of the phytoremediation process (Khan et al. 2015; Furini et al. 2015).

Phytoremediation agents such as A. microphylla are more tolerant towards pollutants in the environment because they can absorb components from the environment that are metabolized inside the tissues (Alkorta et al. 2004; Tulod et al. 2012; Varghese and Jacob 2016; Napaldet et al. 2019 ). In this case, A. microphylla can accumulate large amounts of contaminants into the biomass (Arora et al. 2006). Research by Arora et al. (2006) revealed that $A$. microphylla had the highest bioconcentration potential among the genus Azolla species. A. microphylla absorption capacities were $11.17 \mathrm{ppm}$ TSS/100 gram plant biomass, 426 ppm COD/100 gram plant biomass, $354.67 \mathrm{ppm}$ $\mathrm{BOD} / 100$ gram plant biomass, and $0.05 \mathrm{ppm}_{2} \mathrm{~S} / 100$ gram plant biomass.

The presence of aquatic plants contributes to the growth of microbes that will degrade organic components $(\mathrm{Qu}$ et al. 2017, Riaz et al. 2017). Plants provide nutrients for microbes in the rhizosphere that can enhance the process of waste degradation (Vymazal 2007). A. microphylla growth can also be induced by the rhizobacteria of Pseudomonas $s p$. which acts as a biofertilizer and biostimulant. $P$. aeruginosa produces auxin which plays a role in cell division, cell elongation, lateral root formation and provides phosphate for A. microphylla nutrition (Mardhiana et al. 2017; Santosa et al. 2018; Astriani et al. 2020). Phosphate is a macro element needed for the growth of A. microphylla (Utama et al. 2015). Therefore, the pollutant reduction in A. microphylla and $P$. aeruginosa biomass treatment was better than $A$. microphylla biomass alone. It is concluded that the combination of $A$. microphylla and $P$. aeruginosa could be used to reduce pollutants in bioethanol wastewater, with the most effective treatment being $0.2 \mathrm{~kg}$ of $A$. microphylla biomass with the density of $P$. aeruginosa of $10^{10} \mathrm{cfu} / \mathrm{mL}$.

\section{ACKNOWLEDGEMENTS}

This research at the bioethanol home industry center in Sukoharjo District, Indonesia could be carried out by permission from the authority of Sukoharjo District Environmental Office; so, the author would like to thank you for the permission that was given. Acknowledgments and appreciation were also given to the head and assistant in the Biology Laboratory of UNS Biology Education, which provided facilities and infrastructure for this study. Thanks also to Endra, Tika, and Ririn who have contributed and helped in conducting this research. 


\section{REFERENCES}

Alkorta I, Hernández-Allica J, Becerril JM, Amezaga I, Albizu I, Garbisu C. 2004. Recent findings on the phytoremediation of soils contaminated with environmentally toxic heavy metals and metalloids such as zinc, cadmium, lead, and arsenic. Rev Environ Sci Biotechnol 3 (1): 71-90. DOI: 10.1023/B:RESB.0000040059.70899.3d

Arnol, Arbianus S, Yuliana S, Andi SUA. 2018. Bioreactor design of mine acid wastewater treatment using wetland sediment as source of microbial inoculum of sulfate-reducing bacteria. Hasanuddin Student Journal 2: 254-262 [Indonesian]

Arora A, Saxena S and Sharma DK. 2006. Tolerance and phytoaccumulation of Chromium by three Azolla species. World $J$ Microbiol Biotechnol 22 (2): 97-100. DOI: 10.1007/s11274-0059000-9

Astriani M, Zubaidah S, Abadi AL, Suarsini E. 2020. Pseudomonas plecoglossicida as a novel bacterium for phosphate solubilizing and indole-3-acetic acid-producing from soybean rhizospheric soils of East Java, Indonesia. Biodiversitas 21 (2): 578-586. DOI: $10.13057 /$ biodiv/d210220

Austin B. 1988. Methods in Aquatic Bacteriology. John Willey \& Sons.Thomsons Press Ltd., New Delhi, India.

Carrapiço F. 2017. The Azolla-Anabaena-bacteria association: a case of symbiotic abduction? In: Muggia L, Seckbach J, Grube M (eds) Algal and Cyanobacteria Symbioses. World Scientific Publishing Company, Portugal

Chellaiah ER. 2018. Cadmium (heavy metals) bioremediation by Pseudomonas aeruginosa: a minireview. Appl Water Sci 8 (6): 1-10. DOI: $10.1007 / \mathrm{s} 13201-018-0796-5$

Ekta P, Modi NR. 2018. A review of phytoremediation. J Pharmacog Phytochem 7 (4): 1485-1489

Ekyastuti W, Ekamawanti HA. 2018. Short Communication: The role of microbial rhizosphere in enhancing plant growth of Jatropha curcas in soil contaminated mercury. Biodiversitas 19 (2): 701-705. DOI: 10.13057/biodiv/d190243

Etim EE. 2012. Phytoremediation and its mechanisms; a review. Int J Environ Bioenergy 2 (3): 120-136.

Ewies, JB, Sarina JE, Daniel PYC, and Edward DS. 1998. Bioremediation Principles. MC Graw Hill Companies, Inc. USA.

Furini A, Manara A, DalCorso G. 2015. Editorial: Environmental phytoremediation: plants and microorganisms at work. Front Plant Sci 6: 520. DOI: 10.3389/fpls.2015.00520

Germaine KJ, Byrne J, Liu X, Keohane J, Culhane J, Lally RD. 2015. Ecopiling: a combine phytoremediation and passive biopiling system for remediating hydrocarbon impacted soils at field scale. Front Plant Sci 5: 756. DOI: 10.3389/fpls.2014.00756

Jawetz M, Adelberg's G, Brooks F, Janet S, Butel, Stefhen. 2010. Medical Microbiology. McGraw-Hill Companies Inc, United States of Amerika.

Jenie BSL, Rahayu WP. 1996. Waste handling of food industry.

Jenni B, Isch C, Aragno M. 1989. Nitrogen fixation by new strains of Pseudomonas pseudoflava and related bacteria. J Gen Microbiol 135 (2): 461-467. DOI: 10.1099/00221287-135-2-461

Jorgensen BB. 1982. Mineralization of organic matter in sea bed: The role of sulphate reduction. Nature 296 (5858): 643-645. DOI: $10.1038 / 296643 \mathrm{aO}$

Khan MU, Sessitsch A, Harris M, Fatima K, Imran A, Arslan M. 2015. Cr resistant rhizo and endophytic bacteria associated with Prosopis juliflora and their potential as phytoremediation enhancing agents in metal degraded soils. Front Plant Sci 5: 755. DOI: 10.3389/fpls.2014.00755

Kurniawati Y, Wardoyo SE, Arizal R. 2015. Optimization of the use of electrolyte salts as liquid clear. Natural Science Journals Nusa Bangsa University 5 (1): 30-34. DOI: 10.31938/jsn.v5i1.97 [Indonesian]

Limmer M, Burken J. 2016. Phytovolatilization of organic contaminants. Environ Sci Technol 50 (13): 6632-6643. DOI 10.1021/acs.est.5b04113

Mardhiana, Pradana AP, Adiwena M, Santoso D, Wijaya R, Murtilaksono A. 2017. Use of endophytic bacteria from roots of Cyperus rotundus for biocontrol of Meloidogyne incognita. Biodiversitas 18 (4): 13081315. DOI: $10.13057 /$ biodiv/d180404

Markl H. 1999. Modeling of biogas reactors. In: WIinter J (ed) Biotechnology. 2nd. A Wiley Company, New York.

Maslahat M , Rakhmanika F , Sutamihardja RTM. 2010. Potency of Pseudomonas aeruginosa bacteria in the process of biodegradation of benzene linear sulfonate (LAS) in three types of commercial deterties. Ecolab 4: 55-96. [Indonesian]

Mentari A, Probosunu N \& Adharini RI. 2016. Utilization of Azolla sp. to decrease COD (Chemical Oxygen Demand) Content. Journal of fishing UGM 18: 67-72 [Indonesian]

Morrice JA, Danz NP, Regal RR, Kelly JR, Niemi GJ, Reavie ED, Hollenhorst TP, Axler RP, Trebitz AS, Cotter AM, Peterson GS. 2008. Human influences on water quality in Great Lakes coastal wetlands. Environ Manag 41 (3): 347-357. DOI: 10.1007/s00267-007-9055-5

Napaldet JT, Buot Jr. IE, Zafaralla MT, Lit Jr. IL, Sotto RC. 2019. Effect of phytoremediation on the morpho-anatomical characters of some aquatic macrophytes. Biodiversitas 20 (5): 1289-1302. DOI: $10.13057 /$ biodiv/d200519

Nurcahyani K. 2015. Treatment of wastewater of the alcohol industry using fermentation process. Proceeding of National Seminary Conservation and Utilization of Natural Resources. Sebelas Maret University, Surakarta, 13 January 2015. [Indonesian].

Parbo AP, Irwan E, Syahril N. 2019. The effect of giving detergents to the growth of Azolla microphylla in brackish water. Asian J Aquat Sci 2 (2): 145-152. DOI: 10.31258/ajoas.2.2.145-152

Prabu PC, Udayasoorian C. 2007. Treatment of pulp and paper mill effluent using constructed wetland. Elec J Environ Agric Food Chem 6 (1): 1689-1701

Qaisar M, Ping Z, Jing C, Yousaf H, Jaffar HM, Dong-lei WU, Bao-lan HU. 2007. Journal of Zhejiang University Science A 8: 1126-1140.

Qu M, Li H, Li N, Liu G, Zhao J, Hua Y, Zhu D. 2017. Distribution of atrazine and its phytoremediation by submerged macrophytes in lake sediments. Chemosphere 168: 1515-1522. DOI: 10.1016/j.chemosphere.2016.11.164

Rao JF. 1994. Enzymes in the hydrolysis and ol/otbemig of starch. In: Whistler RL, Bemiller JN, Paschall EF (eds) Starch: Chemistry and Technology. 2" ed. Academic Press. Inc., Orlando.

Riaz G, Tabinda AB, Iqbal S, Yasar A, Abbas M, Khan AM, Baqar M. 2017: Phytoremediation of organochlorine and pyrethroid pesticides by aquatic macrophytes and algae in freshwater systems. Int $\mathrm{J}$ $\begin{array}{lllll}\text { Phytoremed } & 19 & (10): & 894- & 898 .\end{array}$ 10.1080/15226514.2017.1303808

Rohmah SA, Hari RIW, Nur H. 2019. Azolla pinnata plant efficiency in lowering COD (Chemical Oxygen Demand) in liquid vermicelli waste at Arcawinangun Village East Purwokerto District of Banyumas in 2018. Keslingmas 38: 1-123. [Indonesian]

Romayanto MEW, Wiryanto, Sajidan. 2006. Domestic wastewater treatment with aeration and addition of Pseudomonas putida bacteria. Bioteknologi 3 (2): 42-49. DOI: $10.13057 /$ biotek/c030202 [Indonesian]

Sanchez G, Alcantara S, Razoflores E, Revah S. 2005. Oxygen transfer and consumption in a thiosulfate oxidizing bioreactor with sulfur production. Lett Appl Microbiol 41 (2): 141-146. DOI: 10.1111/j.1472-765X.2005.01741.x

Sanna A, Steel L, Valer MMM. 2017. Carbon dioxide sequestration using NaHSO4 and $\mathrm{NaOH}$ : A dissolution and carbonation optimisation study. J Environ Manag 189: 84- 97. DOI: 10.1016/j.jenvman.2016.12.029

Santosa S, Sutarno, Purwanto E, Suranto, Sajidan. 2018. Molecular characterization of Plant Growth Promoting Rhizobacteria using 16S rRNA sequences in the organic rice field of Sukorejo Village, Central Java, Indonesia. Biodiversitas 19 (6): 2157- 2162. DOI: 10.13057/biodiv/d190623

Shah MP, Patel KA, Darji AM. 2013. Microbial degradation and decolorization of methyl orange dye by an application of Pseudomonas spp. ETL-1982. J Environ Bioremed Biodegrad 1 (1): 26-36. DOI:10.12691/ijebb-1-1-5

Sheena KN, Harsha P. 2018. Feasibility study of phytoremediation in wastewater treatment. Int J Sci Res (IJSR) 7: 1019-1026. DOI: 10.21275/ART20182544

Soman D, Anitha V, Arora A. 2018. Bioremediation of municipal sewage water with Azolla microphylla. Int J Adv Res 6 (5): 101-108. DOI: 10.21474/IJAR01/7012

Sood APL, Uniyal R, Rasana ASA. 2011. Phytoremediation potential of aquatic macrophyte, Azolla. Ambio 41 (2): 122-137. DOI: 10.1007/s13280-011-0159-z

Suhendrayatna, Marwan, Andriani R, Fajriana Y, and Elvitriana. 2012. Removal of municipal wastewater BOD, COD, and TSS by phytoreduction: A laboratory-scale comparison of aquatic plants at different species Typha latifolia and Saccharum spontaneum. Int J 
Eng Innov Technol (IJEIT) 2 (6): 333-337. DOI: 10.17605/OSF.IO/RS9VF

Tangahu BV, Ningsih DA, Kurniawan SB, Imron MF. 2019. Study of BOD and COD removal in batik wastewater using Scirpus grossus and Iris pseudacorus with intermittent exposure system. J Ecol Eng 20 (5): 130-134. DOI:10.12911/22998993/105357

Tanner C. 2001. Plants as ecosystem engineers in subsurface-flow treatment wetlands. Water Sci Technol 44 (11-12): 9-17. DOI: 10.2166/wst.2001.0804

Tulod AM, Castillo AS, Carandang WM, Pampolina NM. 2012. Growth performance and phytoremediation of Pongamia pinnata (L.) Pierre, Samanea saman (Jacq.) Merr. and Vitex parviflora Juss. In copper contaminated soil amended with zeolite and VAM. Asia Life Sci 21 (2): 499-522.

Ugya AY, HUA X, MA J. 2019. Phytoremediation as a tool for the remediation of wastewater resulting from dyeing activities. Applied ecology and environmental research 7 (2): 3723-3735. DOI: 10.15666/aeer/1702 37233735

Unisah S, Akbari T. 2020. Processing of tofu wastewater by phytoremediation method plant Azolla microphylla in Tofu Industry B Serang City. Jurnalis 3: 73-86. [Indonesian]

Utama P, Firnia D, Natanael G. 2015. The growth and removals of nitrogen Azolla microphylla due to phosphoric administration and different water elevation. Agrologia 4: 41-52 [Indonesian]

Varghese AR, Jacob L. 2016. Phytoremediation of waterbodies using selected aquatic macrophytes Eichhornia crassipes (Mart.) Solms and Pistia stratiotes, 1. Asian J Sci Technol 7: 2774-2776.
Vymazal J dan Kropfelov L. 2009. A Removal of organics in constructed wetlands with horizontal sub-surface flow: a review of the field experience. Sci Tot Environ 407 (13): 3911-3922. DOI: 10.1016/j.scitotenv.2008.08.032

Vymazal J. 2007. Removal of nutrients in various types of constructed wetlands. Sci Tot Environ 380 (1-3): 48-65. DOI: 10.1016/j.scitotenv.2006.09.014

Wackett LP. 2000. Pseudomonas entering the post-genomic era. Environ Microbiol 2 (3): 348-354. DOI: 10.1046/j.1462-2920.2000.00126.x Wahyudi D, Aman AT, Handayani NSN, Soetarto ES. 2019. Differences among clinical isolates of Pseudomonas aeruginosa in their capability of forming biofilms and their susceptibility to antibiotics. Biodiversitas 20 (5): 1450-1456. DOI: 10.13057/biodiv/d200538

Warzatullisna, Fitri L, Ismail YS. 2019. Potential of endophytic bacteria from rice root as potassium solvent. Biodiversitas 20 (5): 1303-1308. DOI: $10.13057 /$ biodiv/d200520

Wiratno, Syakir M, Sucipto I, Pradana AP. 2019. Isolation and characterization of endophytic bacteria from roots of Piper nigrum and their activities against Fusarium oxysporum and Meloidogyne $\begin{array}{llll}\text { incognita. } & \text { Biodiversitas } 20 & \text { (3): } & 682-687 . \\ \end{array}$ 10.13057/biodiv/d200310

Xin Z, Ai JL, Fang JZ, Guo ZX, Gui LD, Yong GZ. 2008. Arsenic accumulation by the aquatic fern Azolla: Comparison of arsenate uptake, speciation and efflux by $A$. caroliniana and A. filiculoides. Environ Poll 156 (3): 1149-1155. DOI: 10.1016/j.envpol.2008.04.002 